the phenomena of fusion and fragmentation fall neatly into place on the basis of the classical researches of Fischer, which would translate them into the form :-

$$
\begin{aligned}
& \text {. . -CO-CP-NH } \mathrm{NH}_{2}+\mathrm{COOH}-\mathrm{CQ}-\mathrm{NH} \text { - . . } \overrightarrow{-} \\
& \text {. . CO-CP-NH-CO-CQ-NH- . . . + } \mathrm{H}_{2} \mathrm{O} \text {. }
\end{aligned}
$$

A detailed investigation will be published shortly, offering molecular interpretations of a number of genetic and cytological facts, including those relating to the nature of ehromocentres, heterochromatin and euchromatin $^{19}$, the behaviour of the spindle attachment ${ }^{8}$, the nature of chromomeres and of some of the forces between chromosomes ${ }^{8}$. The fundamental approach to the problem is clearly the study of the molecular structure of chromosomes by X-rays. Pending the necessary technical developments we must pursue our inquiries inductively. The central theme of the work-the chromosome as a crystal structure-gives unity and coherence to the task, the considerable body of knowledge of protein molecules in general, including those of globular type ${ }^{20}$, providing a most admirable guide.

Happily, opportunities of testing the hypothesis are not wanting, those rendered possible by the new work on clupein ${ }^{3}$ being specially attractive.

'D. Jordan Lloyd, "The Chemistry of the Proteins". London, 1926. D. Jordan Iloyd "Colloidal Structure and its Biological Signifleance", Biological Rev., 7, 254-273; 1932. D. Jordan Lloyd, "The Movements of Water in Living Organisms", Biological Rev., 8, 463-481 1933 D. Jordan Lloyd and H. Philips, "Protein Structure and
Protein Hydration", Trans. Faraday Soc., 29, 132-146 ; 1933. D. Jordan Lloyd, "The Proteins as Colloidal Electrolytes", Trans. Faraday Soc. (in the press); 1934.

${ }^{2}$ W. T. Astbury, "Fundamentals of Fibre Structure". Oxford, 1933 ${ }^{3} \mathrm{~K}$. Linderstrom-Lang, "Some Electrochemical Properties of a simple Protein", Trans. Faraday Soc. (in the press); 1934.

"D. Jordan Lloyd, "The Combination of Proteins with Acids and Bases;, J. Int. Soc. of Leather Trades' Chemists, 245-258; 1933.

s P. A. Levene and L. W. Bass, "Nucleic Acids". New York, 1932 - P. Reiss, "Le $p \mathrm{H}$ intérieur cellulaire (Thèse pour le Doctorat en Médecine)"' Strasbourg, 1926.

? L. W. Sharp, "Introduction to Cytology". New York, 1934

"C. D. Darlington, "Recent Advances in Cytology", York, 1934. - K. Belar "Beiträge zur Kenntnis des Mechanismus der indirekten Kernteilung," Naturwiss., 36, 725-733; 1929.

Kernteilung", Naturwiss., 36, 725-733; 1929 . of Hair, Wool and related Fibres". Phil. Trans. Roy. Soc., A., 232, $333-394$; 1933 .

${ }^{11} \mathrm{C} . \mathrm{D}$. Darlington, "
logia, 4, $229-240$; 1933 .

${ }^{22}$ M. J. D. White, "Tetraploid Spermatocytes in a Locust, Schis. tocerca gregaria". Cytologia, 5, 135-139; 1933.

${ }^{13}$ L. J. Harris, "Zwitterions: Proof of the Zwitterion Constitution of the Amino-acid Molecule." Biochem. J., 24, 1080-1097; 1930.

${ }^{14} \mathrm{Y}$. Kuwada and T. Nakamura, "Behaviour of Chromonemata in Mitosis". I. Memoirs of College of Science, Kyoto, 9, 129-139; 1933 Y. Kuwada and T. Nakamura, "Behaviour of Chromonemata in Mitosis". II. Cytologia, 5, 244-247; 1934. Y. Kuwada and 'T. Nakamura, "Behaviour of Chromonemata in Mitosis". III. Memoirs of College of Science, Kyoto, 9, 343-366; 1934. N. Shinke, "Spiral Structure of Chromosomes in Meiosis in Sagittaria Aginashi". Memoir of College of Science, Kyoto, 9, 367-392; 1934.

${ }_{15}$ P. Ch. Koller and C. D. Darlington, "The Genetical and Mechanical Properties of Sex Chromosomes". J. Genetics, 29, 159-173; 1934. ${ }_{10}$ A. Friedel, Ann. Phys., 9, 18, 273; 1922. J. D. Bernal, "Liquid Crystals", NatURE, 132, 86 ; 1933. 'W. Bragg, "Liquid Crystals", NATURE, $133,445-456 ; 1934$.

17 Science News Letter, Nov. 10, 1934.

${ }^{28}$ K. H. Meyer and H. Mark, "Der Aufbau der hochpolymeren rganischen Naturstoffe". Leipzig, 1930.

10 E. Heitz, "Die Herkunft der Chromocentren”, Planta, 18, 571639 ; 1932 . "Die somatische Heteropycnose bei Drosophila melanogaster und ihre genetische Bedeutung", Z. Zellforsch. u. mikr. Anat. $20,237-287 ; 1933$.

20 J. D. Bernal and D. Crowfoot, Nature, 133, 794; 1934.

\title{
Brood Diseases of Bees
}

$\mathrm{T}$ HE eighteenth of the Rothamsted conferences was held at the Experimental Station on May 19,1934 , under the chairmanship of Sir John Russell, and was devoted to papers and discussions on the brood diseases of the hive bee. Its proceedings have now been published under the title of "Brood Diseases of Bees".*

Notwithstanding the extensive researches which have been conducted on foul brood diseases of bees, the present knowledge of the subject is still very incomplete. Practically no scientific work has been done in Great Britain on brood diseases since 1885, and such information that is at present available is derived chiefly from the results of investigations carried out in other countries. The advisability of studying this subject in England has been recognised for some years by the Rothamsted authorities, and the advisory committee connected with the apicultural branch of the Experimental Station strongly urged that action should be taken.

Sir John Russell, in his introduction to the published report on the Conference, explains how the means for carrying out the necessary work was obtained. A decisive move was made by the British Bee Keepers' Association, which secured from its constituent bodies subscriptions enabling it to guarantee a sum of $£ 250$ a year for three years. An equivalent amount has been voted by the Agricultural Research Council, and a capital sum of $£ 250$, for the special equipment needed, has been obtained through the generosity of private benefactors. Dr. J. C. G. Ledingham, and the managers of the Lister Institute, have offered the use of their laboratories

* Rothamsted Conferences, 18 : Brood Diseases of Bees. (Secretary, Rothamsted Experimental Station, Harpenden, Herts.) 1s. $6 d$. for any special bacteriological work required. The actual investigations started in the present year when Dr. H. L. A. Tarr was appointed in charge of the work. The Conference, it may be added, was called at the outset of the investigations in order to review the whole subject.

In the printed report, Mr. D. Morland contributes an article on the distribution of foul brood diseases in England, which is based on replies received in response to a questionnaire. The information received indicates the need for a full survey of the incidence, varieties and means of control of brood diseases, rather than any feeling that the data obtained is at all complete or that informants were always correct in their diagnoses. Other contributors discuss the historical aspect of our knowledge of brood diseases and the subject of legislation with reference to bee diseases in other countries. The possible benefit to be derived from legislation, as a means of controlling the spread of brood diseases, suggests itself when the success attendant upon such methods in Switzerland, for example, be taken into account. In reviewing the present position of the scientific study of foul brood diseases, Dr. Tarr lays stress upon the confusion that at present exists as regards this subject. American foul brood, European foul brood, sacbrood and rarer infections are individually discussed. The concluding article by Mr. D. Morland is essentially practical and summarises our knowledge with regard to the symptoms, means of prevention and current methods of treatment of the various diseases in question.

The papers contained in this report provide an excellent summary of the present status of the whole subject : they indicate what is already known and 
where research is most needed. Whereas most investigators agree in ascribing American foul brood to Bacillus larvoe, the etiology of European foul brood remains much in doubt, and the problem is further complicated by the presence of 'secondary invaders' which have often been confused with the primary agent responsible for the disease. Whether this primary agent is Bacillus pluton, as it is generally regarded to be outside Britain, needs much investigation, and the work is hampered by the fact that there are evident difficulties attending its culture. With advance of bacteriological knowledge of the diseases in question, improved methods of diagnosis and treatment may be expected to result, and the work now being undertaken at Rothamsted is directed towards the solution of these problems. A. D. I.

\section{Sleep and}

$I^{N}$ an address on sleep and hypnosis delivered at a meeting of Section J (Psychology) of the British Association at Aberdeen, Dr. William Brown pointed out that although there are marked contrasts between hypnosis and sleep, there is also a close connexion. The muscles in sleep are in a state of relaxation, and in hypnosis in a state of rigidity. In sleep the kneejerks become less pronounced and eventually disappear : in the hypnotic state, however deep, they remain undiminished. There are other differences; for example, in sleep the subject is unable to respond to a suggestion to perform a simple act, whereas even in deep hypnosis such obedience is readily forthcoming. But in spite of these contrasts, Dr. Brown holds that there is a close connexion between the two states. Sleep can be induced by hypnotic suggestion even to the cure of some forms of insomnia, and the hypnotic state itself readily passes into a state of sleep. Sleep-walking is a spontaneously occurring phenomenon closely analogous to what is induced in a good hypnotic subject. A person who frequently walks in his sleep is, as a rule, exceptionally easy to hypnotise, and in the hypnotic state the dreams of the somnambulist may be recalled and the abnormal condition often rectified.

In inducing hypnosis, if the subject is instructed to relax and breathe deeply and regularly, the result is a close approximation to normal sleep, although the total state remains one of hypnosis, the knee-

\section{Hypnosis}

jerks being present, and the power to apprehend and react to the suggestions of the hypnotist continuing In such a mild hypnoidal condition, the subject is unconscious of the outside world, but acutely aware of the hypnotist, and able to concentrate intensely upon certain suggested ideas. In this way, avoiding the unnecessary phenomenon of catalepsy, access may be obtained to some of the deeper levels of nerve function, and therapeutic adjustments can be made.

On the neurological side, the relationship between sleep and hypnosis is probably most accurately given by the theory of I. P. Pavlov, according to which both states involve internal inhibition in the cerebral cortex, spreading to the subcortical centres in the case of the former, and limited to the cortex in the case of the latter.

Mr. R. J. Bartlett reported on association tests with psychotic patients. In free association, complex indicators are progressively exaggerated with in. creasing mental disability, while, with controlled association, the difference from normality varies considerably, being greatest with opposites. Small but significant correlations were obtained between physicians' estimates and test scores, and there are indications that the work may prove of practical value in securing, for the physician, additional contact with the patient's mental troubles, and, for the patient, renewed contact with his own rational past.

\section{Mechanisms of Cellular Respiration}

$\mathrm{I}^{\mathrm{N} \cdot \mathrm{ch}}$ - his Croonian Lecture on the "Mechanisms of Cellular Respiration" delivered to the Royal Society on December 13, Prof. D. Keilin, Quick professor of biology and director of the Molteno Institute in the University of Cambridge, described in some detail the part played by cytochrome in the respiratory process. $\mathrm{He}$ said that cellular respiration consists essentially of the activation of metabolites by dehydrogenases and their coferments : the activated molecules are then oxidised by reacting with a suitable hydrogen acceptor, such as molecular oxygen, cytochrome, Warburg's yellow enzyme, oxidised glutathione, methylene blue or hydrogen peroxide. Of these, cytochrome, the yellow enzyme and glutathione can be re-oxidised by oxygen, thus acting as respiratory catalysts.

The most widely distributed respiratory system in aerobic cells is composed of dehydrogenasesubstrate-cytochrome-oxidase-oxygen. Cytochrome is a mixture of three hæmochromogen compounds, with distinct absorption bands. Its reduction is inhibited by removal of metabolites or addition of narcotics : its oxidation is inhibited by poisons like potassium eyanide, hydrogen sulphide or carbon monoxide.

Haas, working in Warburg's laboratory, has recently arrived at the conclusion that the total respiration of starved yeast cells proceeds through cytochrome, as the result of experiments in which he estimated their cytochrome content, oxygen uptake and time of reduction of oxidised cytochrome after addition of potassium cyanide. The yellow enzyme of Warburg is composed of an active pig. ment group combined with a protein : it acts as a carrier between the activated metabolites and molecular oxygen. The leucoform is easily oxidised by methylene blue and oxygen and requires one molecule of oxygen per molecule of pigment : in the cells of baker's yeast, under aerobic conditions, it is responsible for only 0.5 per cent of the total oxygen uptake.

Certain dehydrogenases, such as xanthine oxidase and uricase, can react directly with oxygen, independently of carriers : both these enzymes are inhibited by potassium cyanide, but not by hydrogen sulphide or carbon monoxide, and both activate their metabolites; in both systems molecular oxygen is reduced to hydrogen peroxide, which can bring about secondary or coupled oxidations. In the cells of certain bacteria, oxidations can take place anaerobically by reactions between two dehydrogenase systems, one metabolite acting as hydrogen donator and the other as hydrogen acceptor : for example, lactate is oxidised to pyruvate while fumarate is reduced to succinate. 